\title{
Effect of Cooling Media on Steel Hardness ST 37 of Conventional Lathe Process
}

\author{
Nelvi Erizon ${ }^{1^{*}}$, M. Iksan Ardiyansyah ${ }^{2}$, Jasman $^{3}$ dan Yufrizal. A $^{4}$ \\ 1,2,3,4 Jurusan Teknik Mesin, Fakultas Teknik, Universitas Negeri Padang
}

\begin{tabular}{l} 
Article Info \\
\hline Article history: \\
Received May $24^{\text {th }}, 2018$ \\
Revised July $01^{\text {st }}, 2018$ \\
Accepted August $14^{\text {th }}, 2018$ \\
\hline
\end{tabular}

Keywords:

Cooling media

Lathe

Steel ST 37

Hardness

\begin{abstract}
This study aims to determine the type of air cooling media, soluble oil, and air to the result on lathe ST 37 steel. The cooling medium is very important to maintain boring tool deformation and can add product quality. In the process lathe of friction between the workpiece and chisel cut that can produce overheating and influence on the result of the slice boring tool on the workpiece. The research that will be carried out is experimental research with variables that are controlled that is feeding, deep of a cut, and spindle rotation and examination of the hardness of the specimen on the object before done lathe. The sample in this study which is ST 37 steel with diameter $25 \mathrm{~mm}$ and length $60 \mathrm{~mm}$ as many as 9 specimens which will be done lathe with different type media kind inprocess working. To know influence the type of cooling medium against steel ST 37 is done brinnel hardeness test using test equipment hardness tester. Of the 9 specimens lathe will be determined 3 points to do hardeness tests. From the result of hardness test and analysis obtained from hardness test on steel ST 37 average data that is use of soluble refrigerant media that produce a very good cooling at the time of the lathe process. The results of research is obtained that the use of soluble refrigerant media is the best with an average hardness of $224.10 \mathrm{~kg} /$ $\mathrm{mm}^{2}$. On the lathe process, the cooling media has oil content will be able to maintain the scores hardness and time-worn on boring tool. Thus to maintain the hardness values can be used soluble oil cooling media and to increase the hardness values of workpieces can be used air cooling media.
\end{abstract}

Copyright (C) 2018 Universitas Negeri Padang. All rights reserved.

\section{Corresponding Author:}

"Nelvi Erizon

Departement of Mechanical, Faculty of Engineering

Universitas Negeri Padang

Jln. Prof. Dr. Hamka Air Tawar, Padang (25131)

Sumatera Barat, Indonesia

Email: nelvi_erizon@yahoo.com

\section{INTRODUCTION}

In line with the progress of science and technology that increasingly rapidly, the development of industrial world in Indonesia usually seen from year to year continue to increase, especially in the field of manufacturing is the production process. Lathe is one kind of machine tool that is used for production equipment.

The principle of the lathe process is the workpiece is tightly bonded to the spindle shaft with the help of a jaw-filled chuck. Then with the circumstances chuck spinning, chisels perform slicing (remove the surface) and move in a linear direction along the long and crosswise with axis rotate. A chisel that moves in the direction of elongation with the workpiece is called the feeding or the distance in which the chisel moves each time the object rotates, while the crosslinking motion crossing the workpiece is called the deep of cut with the distance between the cut surface of the uncuted surface.

Each lathe has the same working principle, but what distinguishes it is the method of lathe and chisel. Thick food and finishing have advantages and risks respectively. The risk of finishing is in the fast rotation of the spindle then the chisel and workpiece temperature increases, causing the chisel to wear faster and excessive heat on the workpiece. Therefore to keep the condition of cutting tools and workpieces in the process of lathe is used cooling media (liquid cooling).

Cooling medium is a tool used for cooling process. In the process of producing the cooling medium is used when the blade and the object experience a touch (wet machining), for example in the process of lathe. 
On cooling the cooling medium acts on the contact between the object and the chisel. Particularly liquid cooling, the coolant has an important use in the machining process, ie removing the beram on the cutting dredges, lubricating the workpiece at low-speed lathing, and cooling the workpiece at high lathe process

Patrick Adebisi (2010) concluded that reducing the cost of cutting tools and increasing production can be achieved through the use of appropriate cutting fluids. In addition to cooling fluid is useful to extend the life of the chisel, some liquid type of coolant is also able to reduce the ratio of cutting tool placement to produce a smooth surface quality but in general the coolant is useful to cool and lubricate workpieces and chisels.

Each coolant has a different characteristic in which each coolant has its own advantages and disadvantages. There are several types of coolant that are used in the industrial world. However, of all types of liquid cooling, Soluble oil type liquid is widely used by industry, the main reason for the type of soluble oil easy to obtain and more efficient in its use. Because the liquid type of soluble oil is a type of emulsion liquid, the type of liquid used as a dispersant phase (solvent) so that more efficient. This study uses a cooling medium commonly used in the lathe process to compare the level of hardness. Fortunately the use of liquid cooling media can be done by direct discharged or flooded.

To know the effect of cooling medium used to hardness of the object we use hardness test. Violence test, is one way of testing the material to know the hardness of a material. Hardness test one type of effective and fast testing to know the hardness of an object In this study violent testing using the type of brinnel testing. Brinnel testing is a type of test suitable for objects that have a low hardness such as ST 37 steel and the roughness of the workpiece is not very influential on the test brinnel.

Acorrding Wirawan Sumbodo (2008) the lathe (turning machine) is a type of machine tool that in the process of working rotate the workpiece and use cutting tools (tools) as a tool to cut the workpiece. There are two types of lathe used for production process. Conventional Lathes are lathe machines operated manually and controlled entirely by the operator, while lathe computer systems are machines whose operations use computer systems, terms and commands in the form of programming $(\mathrm{CNC})$ or $(\mathrm{NC})$, then required trained engine operators. There are three main parameters in each adjustable lathe process: spindle speed (speed), feeding movement and depth of cut. Other factors such as workpiece materials and chisel types actually also have considerable influence, but the above three parameters are the parts that can be set by the operator directly on the lathe.

Testing of materials inside Suharno (2008) done to know the characteristics of a material testing, testing can be divided into 2 ie. the destructive test of the specimen will be damaged after testing, such as tensile test, curve and non-destructive test of the specimen shall not suffer significant damage after testing such as hardness testing, metallography etc.

Acorrding Tata Surdia (2005). Hardness testing is one of the many tests used, because it can be performed on small test pieces without difficulty regarding specifications. The most widely used test is to emphasize a particular emphasis on the specimen with a certain load and by measuring the size of the former emphasis formed above it, this way is called the force of emphasis. Hardness can be defined as the resistance of the metal to the inward pressure load caused by a press object of a particular shape due to the force effect. There are several types of violent testing including the Rockwell Violence Test, Testing Vickers, Brinnel Testing.

Vibration testing by brinnel method is one of testing method by pressing an identor of steel ball to specimen. The Brinell hardness (BHN) is expressed as P load divided by the surface area of the indentation. In practice, this area is calculated from the microscopic measurement of the length of the BHN trace diameter can be determined from the following equation:

$$
B H N=\frac{P}{(\pi D / 2)\left(D-\sqrt{D^{2}-d^{2}}\right)}
$$

Information:

$\mathrm{P}=$ load used $(\mathrm{kg})$

$\mathrm{D}=$ diameter of a steel ball with an identor $(\mathrm{mm})$

$\mathrm{d}=$ the diameter of the identical tread tread on the specimen $(\mathrm{mm})$.

The duration of the brinnel test depends on the material to be tested. For all types of steel usually ranges up to 15 seconds. In brinnel testing it is advantageous for materials that have a hardness of up to $400 \mathrm{HB}$, if testing of the material exceeds that value then the test is recommended using the Rockwell or Vickers test method. 


\section{MATERIAL AND METHOD}

This research is a type of experimental research that compares the variation of cooling media type on the conventional machine bending process to hardness of workpiece with brinnel test. Experimental research, according to Suharsimi Arikunto (2010: 9) experimental research is a way to find a causal relationship (clause relationship) between two factors that deliberately caused by researchers by eliminating or reducing or setting aside other disturbing factors. Experimental research is always done with the intent to see the effect of a treatment. The tool used in this research is 1 set of V13 maximat lathes along with the tool of completeness, and brinnel hardness test.

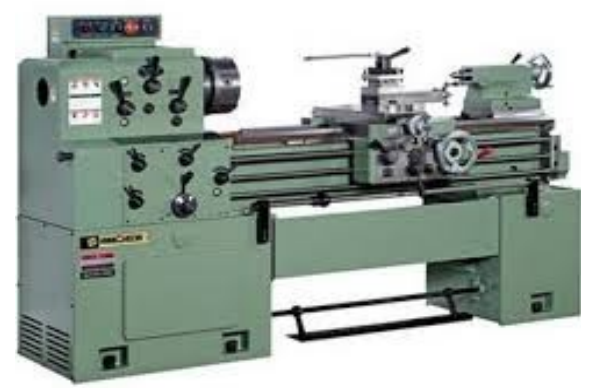

Figure 1. Lathe Maximat V13

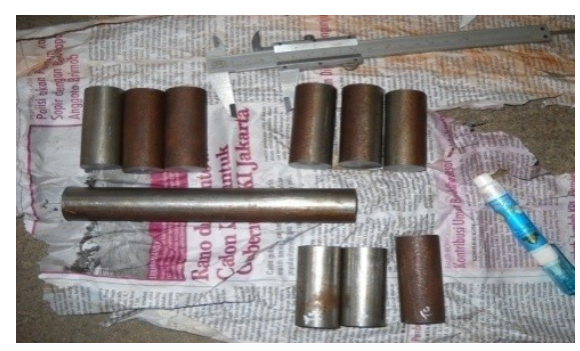

Figure 2. Material testing

Materials or Objects to be studied are low carbon steels $(0.17 \%$ C) ST 37 one of the most widely used types of carbon steel. The method of execution is the material that has been cut, leveled the edges and then the object is done straight turning using HSS chisel. Before performing the test, the workpiece is tested first, during the process of spinning each workpiece using a prepared cooling media type. After that stage is done hardness test. Hardness test (Brinnel) is done at 3 point of workpiece with a predetermined distance from part of each point of workpiece.

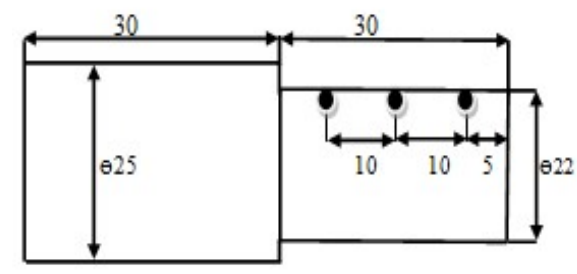

Figure 3. Test specimen

There are 9 specimens used, each object is formed under conditions to make it easier when testing. The last stage in this process is to test the hardness using hardness test unit to search the test data produced. The following images of specimens that have been tested and tested before can be seen in Figure 4: 
Figure 4. Specimens before and after test

\section{RESULT AND DISCUSSION}

Based on the results of hardness testing on the specimens of the results of the lathe with variations of cooling media type that has been done in the laboratory testing materials majoring in Mechanical Engineering, after testing can be searched hardness value at each point by looking at the table of violence value and can be calculated by using the analysis formula of violence testing.

To see average values can use formulas.

$$
M=\frac{\sum x}{n}
$$

Based on the result of hardness test which have been done hence can be seen hardness value all specimen. Hardness values that emerge by using different cooling media have differentiation between each other and vary with each other. This is because there is an effect of cooling media used in the process of lathe.

The following is a table of analysis results of hardness testing data that has been done with different types of cooling media used, among others: soluble oil, water and air.

Table 1. Hardness test result

\begin{tabular}{|c|c|c|c|c|c|c|c|c|c|}
\hline \multirow[b]{2}{*}{$\begin{array}{l}\text { Spesimen } \\
\text { Test }\end{array}$} & \multirow[b]{2}{*}{ No } & \multirow[b]{2}{*}{$\begin{array}{c}\text { Testing } \\
\text { Point }\end{array}$} & \multirow[b]{2}{*}{$\begin{array}{l}\text { Load } \\
\text { (Kgf) }\end{array}$} & \multirow[b]{2}{*}{$\begin{array}{c}\text { Dial } \\
\text { Number }\end{array}$} & \multirow{2}{*}{$\begin{array}{c}\text { Trace } \\
\text { Diameter } \\
(\mathrm{mm})\end{array}$} & \multicolumn{4}{|c|}{ Harga kekerasan Brinell } \\
\hline & & & & & & Thick & $\begin{array}{c}\text { Avarage } \\
\text { (Tabel) }\end{array}$ & Analisis & $\begin{array}{c}\text { Avarage } \\
\text { (Tabel) }\end{array}$ \\
\hline \multirow{10}{*}{$\begin{array}{l}\text { Control } \\
\text { Specimens } \\
\text { (Without } \\
\text { Lathe) }\end{array}$} & \multirow{3}{*}{1} & Point 1 & 187,5 & 53 & 1,1 & 202 & \multirow{3}{*}{204,66} & 196,7491 & \multirow{3}{*}{198,27} \\
\hline & & Point 2 & 187,5 & 53 & 1 & 202 & & 199,0044 & \\
\hline & & Point 3 & 187,5 & 55 & 1 & 210 & & 199,044 & \\
\hline & \multirow{3}{*}{2} & Point 1 & 187,5 & 50 & 1,1 & 190 & \multirow{3}{*}{199,33} & 196,7491 & \multirow{3}{*}{194,94} \\
\hline & & Point 2 & 187,5 & 53 & 1 & 202 & & 199,044 & \\
\hline & & Point 3 & 187,5 & 54 & 1 & 206 & & 199,044 & \\
\hline & \multirow{3}{*}{3} & Point 1 & 187,5 & 52 & 1,1 & 198 & \multirow{3}{*}{200,01} & 196,7491 & \multirow{3}{*}{197,5} \\
\hline & & Point 2 & 187,5 & 51,5 & 1,1 & 196 & & 196,7491 & \\
\hline & & Point 3 & 187,5 & 54 & 1 & 206 & & 199,044 & \\
\hline & \multirow{3}{*}{1} & Point 1 & 187,5 & 55 & 1 & 210 & \multirow{3}{*}{223,66} & 199,044 & \multirow{3}{*}{242,37} \\
\hline \multirow{9}{*}{$\begin{array}{c}\text { Coolant } \\
\text { Cooling } \\
\text { Media } \\
\text { Specimens }\end{array}$} & & Point 2 & 187,5 & 58,5 & 0,95 & 229 & & 264,043 & \\
\hline & & Point 3 & 187,5 & 59 & 0,95 & 232 & & 264,043 & \\
\hline & \multirow{3}{*}{2} & Point 1 & 187,5 & 55 & 1 & 210 & \multirow{3}{*}{222,66} & 199,044 & \multirow{3}{*}{220,7} \\
\hline & & Point 2 & 187,5 & 58 & 1 & 226 & & 199,044 & \\
\hline & & Point 3 & 187,5 & 59 & 0,95 & 232 & & 264,043 & \\
\hline & \multirow{4}{*}{3} & Point 1 & 187,5 & 57 & 1 & 220 & \multirow{3}{*}{226} & 199,044 & \multirow{3}{*}{220,7} \\
\hline & & Point 2 & 187,5 & 59 & 1 & 232 & & 199,044 & \\
\hline & & Point 3 & 187,5 & 58 & 0,95 & 226 & & 264,043 & \\
\hline & & Point 1 & 187,5 & 57 & 1 & 220 & & 199,044 & \\
\hline \multirow{8}{*}{$\begin{array}{c}\text { Water } \\
\text { Cooling } \\
\text { Media } \\
\text { Specimen }\end{array}$} & \multirow[t]{2}{*}{1} & Point 2 & 187,5 & 60 & 0,95 & 238 & 232 & 264,043 & 242,37 \\
\hline & & Point 3 & 187,5 & 60 & 0,95 & 238 & & 264,043 & \\
\hline & & Point 1 & 187,5 & 55 & 1 & 210 & & 199,044 & \\
\hline & 2 & Point 2 & 187,5 & 59 & 0,95 & 232 & 228 & 264,043 & 242,37 \\
\hline & & Point 3 & 187,5 & 61 & 0,95 & 243 & & 264,043 & \\
\hline & & Point 1 & 187,5 & 57 & 1 & 220 & & 199,044 & \\
\hline & 3 & Point 2 & 187,5 & 59 & 0,95 & 232 & 230 & 264,043 & 252,64 \\
\hline & & Point 3 & 187,5 & 60 & 0,9 & 238 & & 295,154 & \\
\hline Air & 1 & Point 1 & 187,5 & 61 & 0,95 & 243 & 263 & 264,043 & 284,11 \\
\hline
\end{tabular}




\begin{tabular}{|c|c|c|c|c|c|c|c|c|c|}
\hline \multirow{8}{*}{$\begin{array}{l}\text { Conditioning } \\
\text { Media } \\
\text { Specimen }\end{array}$} & & Point 2 & 187,5 & 64 & 0,9 & 262 & & 294,154 & \\
\hline & & Point 3 & 187,5 & 67 & 0,9 & 285 & & 294,154 & \\
\hline & & Point 1 & 187,5 & 60 & 0,95 & 238 & & 264,043 & \\
\hline & 2 & Point 2 & 187,5 & 65 & 0,9 & 269 & 266 & 264,043 & 274,07 \\
\hline & & Point 3 & 187,5 & 68 & 0,95 & 293 & & 294,154 & \\
\hline & & Point 1 & 187,5 & 59 & 0,95 & 232 & & 264,043 & \\
\hline & 3 & Point 2 & 187,5 & 65 & 0,9 & 269 & 262 & 294,154 & 294,76 \\
\hline & & Point 3 & 187,5 & 67 & 0,85 & 285 & & 329,099 & \\
\hline
\end{tabular}

Based on the results of test data that has been done, after analyzed to produce the test result graph as follows:

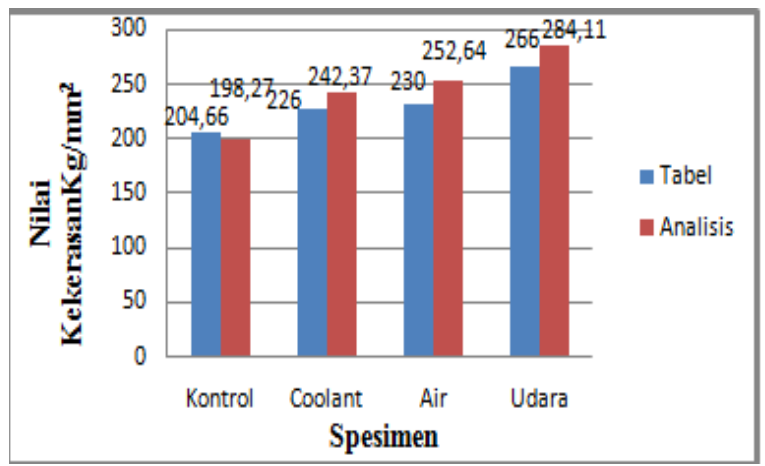

Figure 5. Graph of average test result of media cooling type

Based on the data obtained from the test results, then obtained the hardness value of each specimen with different cooling media. For the highest hardness values based on the table are found on the specimens of the result of the lattering with air cooling medium with hardness value $263,66 \mathrm{Kg} / \mathrm{mm}^{2}$, the second highest value is on specimen with water cooling medium with hardness value $230,2 \mathrm{Kg} / \mathrm{mm}^{2}$. and the smallest hardness value is on coolant coolant media with hardness value $224,10 \mathrm{Kg} / \mathrm{mm}^{2}$.

While based on the analysis of the same results, with the highest hardness value found in specimens with air cooling media with a hardness of $284.31 \mathrm{Kg} / \mathrm{mm}^{2}$, and the second highest is using water cooling media with a value of hardness $245.79 \mathrm{Kg} / \mathrm{mm}^{2}$, and value the smallest on coolant coolant medium with hardness value $227.92 \mathrm{Kg} / \mathrm{mm}^{2}$.

From these statements it can be concluded that if the lathe is expected to increase the hardness value it can be used air cooling media or without cooling. "And vice versa in the process of slicing the workpiece by using liquid cooling medium and oil based will be better able to maintain temperature and hardness value of workpiece.

In accordance with the results of research that has been done then the results of this study can be recommended in the selection of cooling media during the process of lathing on ST 37 carbon steel. In addition to the recommendations of this study can also be applied to large industries and small industries, the most important must be in accordance with procedures that have been there for the results obtained can be more leverage.

\section{CONCLUSION}

Based on research that has been done by the researcher that can be concluded. The cooling medium affects the value of hardness of the lathe and the wear resistance of the chisel. After the specimen will be subjected to violent changes. Control specimens (specimens tested prior to the lathe process) have a hardness of $201.33 \mathrm{~kg} / \mathrm{mm}^{2}$.

Air cooling media has the highest hardness value compared to other cooling media that is equal to $284,31 \mathrm{~kg} / \mathrm{mm}^{2}$. By using cooling medium, coolant cooling medium has the smallest hardness value that is $227,92 \mathrm{~kg} / \mathrm{mm}^{2}$ compared to water cooling media $245,79 \mathrm{~kg} / \mathrm{mm}^{2}$ and air $284,31 \mathrm{~kg} / \mathrm{mm}^{2}$. In the lathe process to maintain and stabilize the value of hardness thus the cooling medium is strongly recommended in the process of lathe, due to make production $\mathrm{m}$ smooth and neat. In accordance with the result for further research there are some suggestions medium is preferably used in lathe, in additic

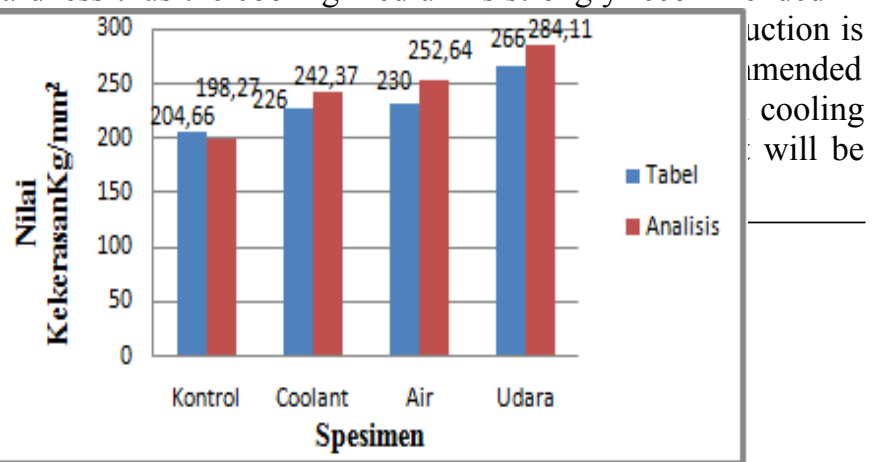


better. (2) It is expected that the next researcher can investigate the cause of the change of hardness due to cooling medium with refrigerant media more varied. (3) For further research please understand the concept before doing research and meticulously in doing research in order to have valid data. (4) For the next researcher is expected to really pay attention to the parameters in the lathe and control the rotation speed along with the geometry chisel lathe.

\section{ACKNOWLEDGEMENTS}

The authors wish to express their thanks to Department of Mechanical Engineering, Faculty of Engineering, Universitas Negeri Padang for supporting this research.

\section{REFERENCES}

[1] Bima Aditya. (2013). "Pengaruh kedalaman dan cairan pendingin terhadap kekerasan dan kekasaran permukaan pada proses bubut konvensional". Jurnal skrispi Strata 1. Unversitas Negeri Surabaya.

[2] Patrick Adebisi Olusegun Adegbuyi Dkk. (2010)." Analysing the effect of cutting fluids on the mechanical properties of mild steel in a turning operation". Department of Mechanical Engineering, Lagos State University, P M B 1087 Apapa-Lagos, Nigeria.

[3] Suharno. (2008). Prinsip-prinsip Teknologi dan Metalurgi Pengelasan Logam. Solo. LPP UNS dan UNS Press.

[4] Tata Surdia dan Shinroku Shaito. 2005. Pengetahuan Bahan Teknik. Jakarta: PT. Pradnya Paramita

[5] Suharsimi, Arikunto (2010). Prosedur Penelitian. Jakarta : Rineka Cipta.

[6] Widarto. (2008)."Teknik Pemesinan jilid 2".Jakarta: Depdiknas.

[7] Wirawan Sumbodo. (2008).”Teknik Produksi dan Mesin Industrii”.Jakarta: Depdikbud 